\title{
Pengembangan Metode Pengusangan Cepat Fisik Benih Pepaya (Carica papaya L.)
}

\section{Physicall Accelerated Aging Method Development in Papaya (Carica papaya L.) Seed}

\author{
Dyah Priandini ${ }^{1}$, Muhamad Rahmad Suhartanto ${ }^{1,2^{*}}$, dan Abdul Qadir $^{1}$ \\ ${ }^{1}$ Departemen Agronomi dan Hortikultura, Fakultas Pertanian, Institut Pertanian Bogor (Bogor Agricultural University), \\ Jalan Meranti, Kampus IPB Darmaga, Bogor 16680, Indonesia. \\ ${ }^{2}$ Pusat Kajian Hortikultura Tropika, Lembaga Penelitian dan Pengabdian kepada Masyarakat Institut Pertanian Bogor, \\ Jl. Raya Pajajaran, Kampus IPB Baranangsiang, Bogor, Indonesia
}

Diterima 4 Oktober 2018/Disetujui 22 Oktober 2018

\begin{abstract}
Development of papaya fruit production is influenced by the availability of seed quality. High seed quality is maintained during seed storage. Estimation of vigor in relation to storability can be detected by accelerated aging test. This research aims to develop physicall accelerated aging test by, 1) determine the impact of physical accelerated aging on vigor and viability parameters on papaya seed variety Callina and Sukma, 2) determine the levels of seed moisture content and effective period of physicall accelerated aging to predict vigor of papaya seed. This research was conducted at the Laboratory of Seed Science and Technology and Green House Leuwikopo, Department of Agronomy and Horticulture, IPB in January-May 2016 using a randomized complete block design with three replications. Seeds aged by the aging equipment MPC IPB 77-1 MMM. The results showed that the aging time decreased germination value in papaya seed variety Callina and Sukma with equation $y=-0.1389 x^{3}+3.3333 x^{2}-25.25 x+81.5$ and $y=0.0171 x^{3}+0.2028 x^{2}-9.9956 x+81.095$. Effective imbibition was 96 hour with moisture content $63-70 \%$ in both varieties. The effective of aging time treatment at $0 \times 4,1 \times 4,2 \times 4,3 \times 4$, dan $4 \times 4$ minutes.
\end{abstract}

Keywords:imbibition, moisture content, viability, vigor

\section{ABSTRAK}

Pengembangan produksi buah pepaya salah satunya dipengaruhi oleh ketersediaan benih bermutu. Mutu benih dipertahankan tinggi selama proses penyimpanan. Salah satu metode yang dapat digunakan dalam pendugaan vigor daya simpan yaitu pengusangan cepat (accelerated aging). Penelitian ini bertujuan untuk mengembangkan metode pengusangan cepat fisik dengan, 1) mengetahui dampak pengusangan cepat fisik terhadap parameter vigor dan viabilitas benih pepaya varietas Callina dan Sukma, 2) mengetahui waktu pelembaban dan waktu pengusangan efektif untuk menduga penurunan vigor benih pepaya. Penelitian ini dilaksanakan di Laboratorium Ilmu dan Teknologi Benih dan Rumah Kaca, Kebun Percobaan Leuwikopo, Departemen Agronomi dan Hortikultura, IPB pada bulan Januari - Mei 2016. Rancangan yang digunakan pada penelitian ini adalah rancangan kelompok lengkap teracak dengan tiga ulangan. Benih diusangkan pada MPC (Mesin Pengusangan Cepat) IPB 77-1 MMM. Hasil penelitian menunjukkan bahwa pengusangan menurunkan daya berkecambah benih pepaya varietas Callina dan Sukma dengan persamaan $y=-0.1389 x^{3}+3.3333 x^{2}-25.25 x+81.5$ dan $y=0.0171 x^{3}+0.2028 x^{2}-9.9956 x+81.095$. Waktu pelembaban optimum untuk benih pepaya varietas Callina dan Sukma adalah 96 jam dengan kadar air 63-70\%. Pengusangan fisik benih pepaya efektif dilaksanakan pada waktu 0x4, 1x4, 2x4, 3x4, dan $4 \times 4$ menit.

Kata kunci: kadar air, pelembaban, viabilitas, vigor

\section{PENDAHULUAN}

Pengembangan agribisnis pepaya merupakan usaha yang potensial. Konsumsi rumah tangga komoditas pepaya mengalami peningkatan pada tahun 2014 sebesar $2.086 \mathrm{~kg} /$ kapita/tahun yang sebelumnya sebesar $1.825 \mathrm{~kg} / \mathrm{kapita} /$ tahun

\footnotetext{
* Penulis untuk korespondensi. e-mail: tantosuhartanto63@gmail. com
}

di tahun 2013 (Kementan, 2015). Tingginya permintaan buah pepaya perlu diimbangi dengan peningkatan produksi buah pepaya. Produksi buah pepaya di Indonesia pada tahun 2014 sebesar 840,119 ton. Jumlah ini mengalami penurunan dari tahun 2013 yaitu sebesar 871,275 ton (BPS, 2015). Pengembangan produksi buah pepaya salah satunya dipengaruhi oleh ketersediaan benih. Ketersediaan benih yang bermutu masih menjadi hambatan dalam pengembangan produksi buah pepaya (Balitbu, 2011). 
Proses pengadaan benih pepaya memerlukan perhatian guna menjaga viabilitasnya agar tetap baik. Faktor penting yang perlu diketahui sebelum melakukan penyimpanan benih antara lain adalah sifat benih yang akan disimpan. Menurut Wulandari (2009) benih pepaya bersifat ortodoks (Varietas Sukma dan Callina) karena tahan simpan pada suhu $\pm-20^{\circ} \mathrm{C}$ dan intermediet (Varietas Arum Bogor) karena tidak tahan simpan pada suhu $\pm-20{ }^{\circ} \mathrm{C}$. Benih pepaya yang bersifat ortodoks memungkinkan disimpan untuk periode jangka panjang.

Penyimpanan benih merupakan salah satu hal yang menjadi perhatian dalam industri benih. Suatu lot benih dapat disimpan selama tidak melebihi daya simpan dari benih tersebut. Daya simpan benih adalah kemampuan maksimal benih untuk dapat disimpan dalam suatu periode waktu dan kondisi tertentu. Informasi vigor daya simpan benih $\left(\mathrm{V}_{\mathrm{DS}}\right)$ dapat dimanfaatkan produsen benih agar terhindar dari kerugian akibat penurunan vigor benih selama periode simpan (Suhartanto, 2012). Vigor daya simpan benih merupakan salah satu tolok ukur pengujian vigor benih. Metode yang dapat digunakan dalam pengujian vigor benih diantaranya pengusangan cepat (accelerated agingtest). Perlakuan pengusangan cepat terdiri dari perlakuan fisik menggunakan suhu dan kelembaban nisbi yang tinggi dan perlakuan kimiawi dengan menggunakan uap jenuh etanol. Pengusangan cepat akan mendera benih pada kondisi suhu tinggi $\left(41^{\circ} \mathrm{C}\right)$ dan kelembaban relatif $( \pm 100 \%)$ dalam waktu singkat. Benih-benih tersebut kemudian dikeluarkan dari kondisi stres dan dikecambahkan dalam kondisi optimal (Copeland dan McDonald, 2001). Metode pengusangan cepat fisik dapat dilakukan menggunakan alat pengusangan cepat yang diberi kode MPC IPB 77-1 MMM (Suhartanto, 2012).

Penelitian devigorasi benih pepaya belum banyak dilakukan. Devigorasi benih dalam pengusangan cepat fisik salah satunya dipengaruhi oleh waktu pelembaban serta waktu pengusangan benih. Pelembaban benih dilakukan untuk meningkatkan kadar air benih hingga mencapai taraf tertentu sebelum pengusangan dilakukan pada suhu tinggi (Budiman, 2012). Peningkatan kadar air akan mempercepat metabolisme benih sehingga pengusangan benih dapat dimulai. Penelitian tentang dampak pengusangan benih, waktu pelembaban benih dan waktu pengusangan benih pepaya diperlukan sebagai tahapan awal pengembangan metode pengusangan yang cepat, mudah, tepat dan efektif. Penelitian ini bertujuan untuk mengetahui pengaruh pengusangan cepat fisik terhadap parameter vigor dan viabilitas benih pepaya varietas Callina dan Sukma serta mengetahui waktu pelembaban dan waktu pengusangan efektif untuk menduga penurunan vigor benih pepaya.

\section{BAHAN DAN METODE}

Penelitian ini dilaksanakan di Laboratorium Ilmu dan Teknologi Benih dan Rumah Kaca, Kebun Percobaan Leuwikopo, Departemen Agronomi dan Hortikultura, Fakultas Pertanian, Institut Pertanian Bogor. Penelitian ini dilaksanakan pada bulan Januari-Juni 2016. Bahan percobaan yang digunakan adalah benih pepaya varietas Callina dan Sukma. Buah pepaya diperoleh dari Pusat Kajian Hortikultura Tropika (PKHT) Bogor. Bahan lain yang digunakan adalah air, aquades, pasir yang telah disterilisasi, kertas buram dan kertas tisu. Alat-alat yang digunakan meliputi alat-alat ekstraksi benih, alat-alat pengukur kadar air, mesin pengusangan cepat (MPC) IPB 77-1 MMM, hygrothermometer serta alat pengecambahan benih. Alatalat ekstraksi benih meliputi pisau, nampan, kipas angin, blower dan alat pembagi tepat. Alat-alat pengukur kadar air meliputi neraca analitik, cawan,oven, dan desikator. Alat-alat pengecambah benih yaitu boks plastik dan hand sprayer.

Penelitian ini dilaksanakan dalam dua percobaan. Percobaan I bertujuan untuk mengetahui dampak pengusangan cepat fisik terhadap viabilitas dan vigor benih. Percobaan II bertujuan untuk mengetahui waktu pelembaban dan waktu pengusangan efektif benih pepaya. Tahapan pertama dalam penelitian ini adalah ekstraksi benih pepaya. Benih pepaya varietas Callina dan Sukma diekstraksi pada dua waktu yang berbeda. Benih yang digunakan dalam penelitian ini merupakan ekstraksi dua pertiga bagian ujung buah pepaya yang telah masak pohon (memiliki 80-90\% semburat kuning merata pada kulit buah). Buah pepaya yang memiliki semburat kuning 30-40\% yang diikuti pemeraman selama empat hari memiliki mutu yang sama baiknya dengan buah masak pohon. Buah yang dipanen saat semburat 30$40 \%$ kuning diikuti pemeraman selama empat hari nyata memiliki potensi tumbuh maksimum, daya berkecambah, kecepatan tumbuh benih, first count germination yang meningkat dan sama dengan buah masak pohon (Murniati et al., 2008). Buah tersebut direndam dalam air selama 24 jam kemudian dibersihkan dari sarcotesta. Pembersihan benih secara manual dan dibilas di air mengalir. Benih dikeringanginkan selama 3-4 hari pada cuaca cerah hingga mencapai kadar air 6-9\% (Suhartanto et al., 2011).

Tahapan kedua adalah pelembaban lima lot benih pepaya. Benih sebelumnya dimasukkan dalam blower untuk memisahkan benih yang hampa. Pembagian lima lot benih menggunakan alat pembagi tepat agar tiap lot benih homogen. Benih seberat 3-4 gram dilembapkan diantara enam lembar kertas buram yang telah diberi air sesuai dengan kapasitas lapang kertas dan dilapisi plastik PP. Volume air untuk melembapkan kertas yaitu $50 \mathrm{~mL}$. Pelembaban benih bertujuan untuk memulai proses imbibisi sehingga memudahkan uap panas masuk ke dalam benih selama pengusangan berlangsung. Penentuan waktu pelembaban berdasarkan batas akhir benih sebelum mulai berkecambah yang dilakukan pada tahapan pra penelitian. Pelembaban benih dilaksanakan selama lima hari.

Tahapan ketiga adalah pengusangan cepat fisik benih menggunakan MPC IPB 77-1 MMM yang diawali dengan pengukuran kadar air benih setelah pelembaban. Pengusangan cepat fisik dilakukan dengan memanaskan air sebanyak $900 \mathrm{~mL}$ selama $\pm 1 \mathrm{jam}$. Benih pepaya siap diusangkan setelah suhu $\left(50-52^{\circ} \mathrm{C}\right)$ dan kelembaban (RH 87$90 \%$ ) di dalam ruang deraan konstan. Benih dikecambahkan pada media pengecambahan berupa tiga lapis kertas buram 
ditambah tiga lembar kertas tisu pada bagian dasar. Media dikondisikan dalam kondisi lembap dan ditempatkan pada boks plastik berukuran 3,500 mL. Media diletakkan di rumah kaca dengan suhu $\pm 30{ }^{\circ} \mathrm{C}$ dan $\mathrm{RH} 25-60 \%$. Pengamatan meliputi pengukuran kadar air benih, indeks vigor, daya berkecambah serta potensi tumbuh maksimum.

Percobaan II merupakan evaluasi hasil dari percobaan I untuk mendapatkan kadar air dan lama pengusangan efektif pada benih. Percobaan II dalam penentuan kadar air efektif menggunakan prosedur yang sama dengan percobaan I. Kelima lot benih tersebut diberi perlakuan pelembaban yaitu pelembaban benih (Pi) selama 24 jam $\left(\mathrm{P}_{1}\right), 48$ jam $\left(\mathrm{P}_{2}\right), 72$ jam $\left(\mathrm{P}_{3}\right), 96$ jam $\left(\mathrm{P}_{4}\right)$, dan 120 jam $\left(\mathrm{P}_{5}\right)$. Benih yang telah diberi perlakuan pelembaban kemudian diusangkan menggunakan alat MPC IPB 77-1 MMM melalui proses pemanasan $900 \mathrm{~mL}$ air selama \pm 1 jam pada suhu $50-52^{\circ} \mathrm{C}$. Benih diusangkan pada waktu 0 menit $\left(\mathrm{W}_{1}\right), 1 \times 4$ menit $\left(\mathrm{W}_{2}\right)$, $2 \times 4$ menit $\left(\mathrm{W}_{3}\right), 3 \times 4$ menit $\left(\mathrm{W}_{4}\right)$ dan $4 \times 4$ menit $\left(\mathrm{W}_{5}\right)$. Benih selanjutnya dikecambahkan pada media pengecambahan. Tolok ukur yang diamati adalah kadar air benih, indeks vigor, daya berkecambah serta potensi tumbuh maksimum. Data dianalisis menggunakan analisis ragam (uji F) dengan taraf $\alpha=5 \%$. Analisis regresi polinomial digunakan untuk mengetahui dampak pengusangan cepat fisik terhadap parameter vigor dan viabilitas benih pepaya varietas Callina dan Sukma.

\section{HASIL DAN PEMBAHASAN}

\section{Pengaruh Pengusangan Cepat Fisik Terhadap Viabilitas dan Vigor Benih}

Percobaan I bertujuan untuk mengetahui pengaruh pengusangan cepat fisik terhadap viabilitas dan vigor benih pepaya. Waktu pengusangan fisik pertama yang digunakan adalah selama $0.1 \times 30,2 \times 30,3 \times 30,4 \times 30$ menit. Suhu dan kelembaban dalam ruang deraan MPC IPB 77-1 MMM adalah $\pm 52{ }^{\circ} \mathrm{C}$ dan $\pm 90 \%$. Viabilitas benih pepaya hasil pengusangan fisik pada rentang waktu tersebut mengalami penurunan secara tajam dari viabilitas awal benih pepaya varietas Callina sebesar 96\% menjadi 0\%. Viabilitas awal benih pepaya varietas Sukma sebesar 93\% menurun drastis menjadi $0 \%$. Periode pengusangan yang terlalu lama diduga menjadi penyebab utama kematian benih pada kedua varietas. Benih yang tumbuh hanya pada perlakuan pengusangan 0 menit, maka rentang waktu pengusangan harus dipersempit kembali.

Waktu pengusangan fisik kedua yang digunakan adalah selama $0.1 \times 7,2 \times 7,3 \times 7,4 \times 7$ menit. Benih mampu berkecambah pada pengusangan $0,1 \times 7,2 \times 7$ menit namun viabilitasnya sangat rendah, yaitu dibawah 5\%. Pengulangan proses pengecambahan dalam penelitian ini disebabkan oleh terjadinya pengerasan media pasir. Metode pengecambahan diubah menjadi metode Uji Diatas Kertas (UDK). Nilai viabilitas benih pada pengujian ini belum menunjukkan hasil optimum sehingga rentang waktu pengusangan dipersempit menjadi $0.1 \times 3,2 \times 3,3 \times 3,4 \times 3$ menit. Waktu pengusangan fisik ketiga menghasilkan nilai rataan status viabilitas, vigor dan kadar air benih pepaya varietas Callina disajikan dalam
Tabel 1. Hasil pengamatan pengecambahan benih pepaya varietas Callina setelah diusangkan secara fisik menunjukkan perbedaan nyata pada kadar air dan daya berkecambah. Benih pepaya mengalami penurunan viabilitas karena didera pada suhu di atas suhu optimum pengecambahan benih papaya. Bhattacharya dan Khuspe (2000) menyebutkan bahwa persentase perkecambahan maksimum benih pepaya pada suhu $30{ }^{\circ} \mathrm{C}$. Nilai kadar air benih pepaya varietas Callina cenderung stabil dan berada pada 63-66\%. Indeks vigor benih pepaya varietas Callina memiliki nilai tengah kurang dari $20 \%$ pada semua perlakuan. Rendahnya indeks vigor benih pepaya dimungkinkan belum optimalnya kemampuan benih untuk berkecambah normal akibat adanya infeksi cendawan sekunder pada hitungan pertama (first count). Menurut Wiati (2016) cendawan yang terbawa benih pepaya meliputi Fusarium sp., Rhizopus sp., Aspergillus sp. serta unidentified fungus. Infeksi cendawan sekunder pada penelitian ini disebabkan oleh cendawan Rhizopus sp. dan Aspergillus sp.

Benih pepaya tetap mampu berkecambah optimum pada akhir pengamatan dilihat dari nilai daya berkecambah serta nilai potensi tumbuh maksimum yang cukup tinggi yaitu pada 92-96\%. Pengaruh pengusangan cepat fisik terhadap daya berkecambah benih pepaya varietas Callina disajikan dalam Gambar 1. Pola penurunan viabilitas benih pepaya selama pengusangan cepat fisik berwujud kurva regresi polinomial (kubik). Analisis regresi secara kubik pada data ini menghasilkan nilai koefisien determinasi $\left(\mathrm{R}^{2}\right)$ yang paling tinggi dibandingkan pola regresi lainnya seperti linear dan kuadratik. Berdasarkan hasil dari analisis regresi dan korelasi, daya berkecambah memiliki nilai koefisien korelasi mendekati satu ( $\mathrm{r}$ yaitu 0.9515 . Hal ini menunjukkan bahwa adanya keeratan hubungan antara lama waktu pengusangan dengan daya berkecambah benih pepaya varietas Callina. Semakin lama waktu pengusangan

Tabel 1. Nilai rata-rata status viabilitas, vigor dan kadar air benih pepaya varietas Callina setelah pengusangan

\begin{tabular}{lcccc}
\hline Perlakuan & KA $(\%)$ & IV $(\%)^{\mathrm{T}}$ & DB $(\%)$ & PTM $(\%)$ \\
\hline 0x3 menit & $64.3 \mathrm{~b}$ & 5.3 & $82.0 \mathrm{a}$ & 92.7 \\
1×3 menit & $63.1 \mathrm{a}$ & 4 & $30.0 \mathrm{~b}$ & 94.7 \\
2x3 menit & $66.0 \mathrm{a}$ & 3.3 & $23.0 \mathrm{~b}$ & 94.7 \\
$3 \times 3$ menit & $66.2 \mathrm{a}$ & 2.7 & $21.0 \mathrm{~b}$ & 92 \\
4x3 menit & $66.1 \mathrm{a}$ & 2.7 & $19.0 \mathrm{~b}$ & 93.3 \\
\hline Pr>F & 0.003 & 0.165 & 0.000 & 0.931 \\
KK (\%) & 1.176 & 18.8318 & 18.931 & 4.934 \\
\hline
\end{tabular}

Keterangan $: \mathrm{KA}=$ kadar air, $\mathrm{IV}=$ indeks vigor, $\mathrm{DB}=$ daya berkecambah, PTM = potensi tumbuh maksimum, $\mathrm{T}$ data ditransformasikan ke $(\mathrm{x}+0,5) 1 / 2$. Angkaangka yang diikuti oleh huruf yang sama pada kolom yang tidak berbeda nyata pada $\alpha=5 \%$, KK = koefisien keragaman. 
benih pepaya varietas Callina di MPC IPB 77-1 MMM, daya berkecambah benih pepaya varietas Callina juga semakin menurun.

Perlakuan pengusangan cepat fisik menurunkan daya berkecambah secara tajam pada pengusangan tiga menit pertama dan cenderung landai pada waktu pengusangan setelahnya. Hal ini sesuai dengan penelitian Demir dan Mavi (2010) yang menyatakan bahwa pengusangan cepat berkorelasi dengan penurunan mutu benih (deteriorasi). Nilai rata-rata status viabilitas, vigor dan kadar air benih pepaya varietas Sukma disajikan dalam Tabel 2. Hasil pengamatan pengecambahan benih pepaya varietas Sukma setelah diusangkan secara fisik menunjukkan perbedaan nyata pada nilai indeks vigor, daya berkecambah dan potensi tumbuh maksimum benih pepaya varietas Callina. Hal ini sesuai dengan hasil penelitian Suhartanto (1994) bahwa devigorasi secara fisik dengan menggunakan uap air panas dapat menciptakan kondisi lembab dan panas pada benih, sehingga dapat mengakibatkan penurunan viabilitas benih secara gradual. Penurunan viabilitas benih pepaya Sukma disajikan dalam Gambar 2.

Nilai viabilitas benih pepaya varietas Sukma pada tolok ukur indeks vigor, daya berkecambah serta potensi tumbuh maksimum cenderung mengikuti pola penurunan secara kubik. Analisis regresi secara kubik pada data ini menghasilkan nilai koefisien determinasi $\left(\mathrm{R}^{2}\right)$ yang paling tinggi dibandingkan pola regresi lainnya seperti linear dan kuadratik. Nilai r pada tolok ukur indeks vigor, daya berkecambah serta potensi tumbuh maksimum mendekati satu (r1) maka terdapat hubungan yang sangat erat antara lama waktu pengusangan dengan tolok ukur tersebut. Pola penurunan daya berkecambah, indeks vigor serta potensi tumbuh maksimum benih cenderung gradual pada pengusangan $0.1 \times 3,2 \times 3$, dan $3 \times 3$ menit dan landai pada

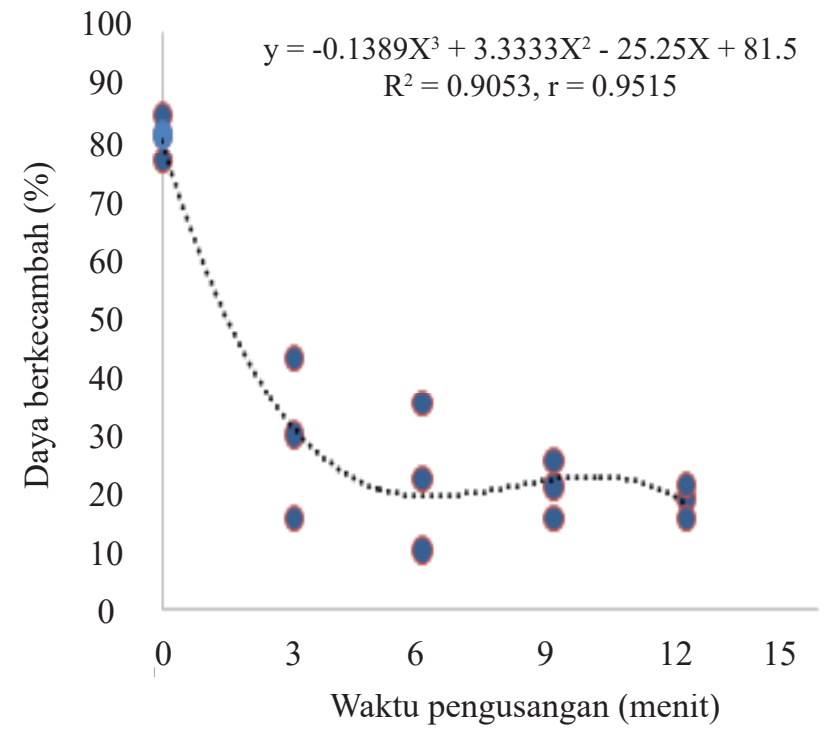

Gambar 1. Pengaruh pengusangan cepat fisik terhadap daya berkecambah benih pepaya varietas Callina pengusangan 4x3 menit. Badriah (2012) menyatakan bahwa terdapat keeratan yang sangat kuat antara lama waktu pengusangan dengan peubah indeks vigor, daya berkecambah, dan potensi tumbuh maksimum.

Tatipata et al. (2004) menyatakan bahwa suhu dan kelembaban yang tinggi akan mempercepat kemunduran benih akibat penurunan aktivitas enzim, meningkatnya nilai konduktivitas, penurunan daya berkecambah dan vigor serta penurunan cadangan makanan. Menurut Justice dan Bass (2002) perombakan cadangan makanan benih menyebabkan terjadinya serangkaian proses metabolisme yang dapat menurunkan viabilitas benih. Vigor menurun lebih cepat dibandingkan viabilitas. Hal ini dapat dilihat dari kurva penurunan indeks vigor lebih rendah dibanding kurva penurunan daya berkecambah benih.

\section{Penentuan Waktu Pelembaban dan Waktu Pengusangan Efektif}

Percobaan II bertujuan untuk menentukan waktu pelembaban dan waktu pengusangan efektif pada benih pepaya. Percobaan ini merupakan evaluasi dari hasil percobaan I dengan lima taraf yaitu waktu pelembaban benih. Evaluasi hasil menggunakan waktu pengusangan fisik pada $0,1 \times 4,2 \times 4,3 \times 4,4 \times 4$ menit. Rekapitulasi hasil analisis regresi dan korelasi terhadap benih pepaya varietas Callina disajikan dalam Tabel 3.

Waktu pelembaban paling efektif dapat ditentukan dari nilai koefisien determinasi $\left(\mathrm{R}^{2}\right)$ mendekati 1 , koefisien regresi (r) mendekati 1 atau -1 serta mempertimbangkan pola penurunan viabilitas dan vigor tiap hari pelembaban. Berdasarkan hasil analisis regresi dan korelasi benih pepaya varietas Callina yang menggambarkan hubungan antara waktu pengusangan cepat fisik (x) dengan parameter viabilitas, vigor dan kadar air benih (y), nilai koefisien

Tabel 2. Nilai rata-rata status viabilitas, vigor dan kadar air benih pepaya varietas Sukma setelah pengusangan

\begin{tabular}{lcccc}
\hline Perlakuan & KA $(\%)$ & IV $(\%)^{\mathrm{T}}$ & DB $(\%)^{\mathrm{T}}$ & PTM $(\%)^{\mathrm{T}}$ \\
\hline 0x3 menit & 70.6 & $30.0 \mathrm{a}$ & $81.1 \mathrm{a}$ & $92.2 \mathrm{a}$ \\
$1 \times 3$ menit & 71 & $22.0 \mathrm{ab}$ & $53.3 \mathrm{~b}$ & $60.7 \mathrm{~b}$ \\
$2 \times 3$ menit & 66.8 & $17.8 \mathrm{bc}$ & $32.2 \mathrm{c}$ & $46.5 \mathrm{bc}$ \\
$3 \times 3$ menit & 67.9 & $8.9 \mathrm{c}$ & $20.0 \mathrm{c}$ & $31.1 \mathrm{c}$ \\
$4 \times 3$ menit & 69 & $11.1 \mathrm{c}$ & $20.0 \mathrm{c}$ & $28.9 \mathrm{c}$ \\
\hline Pr $>\mathrm{F}$ & 0.181 & 0.005 & 0.000 & 0.001 \\
KK $(\%)$ & 2.880 & 14.3532 & 16.0838 & 11.2223 \\
\hline
\end{tabular}

Keterangan: $\mathrm{KA}=$ kadar air, IV = indeks vigor, $\mathrm{DB}$ : daya berkecambah, PTM = potensi tumbuh maksimum. T data ditransformasikan $\mathrm{ke}(\mathrm{x}+0.5) 1 / 2$. Angka-angka yang diikuti oleh huruf yang sama pada kolom yang sama tidak berbeda nyata pada uji DMRT pada taraf $\alpha=$ $5 \%, \mathrm{KK}=$ koefisien keragaman. 
korelasi (r) yang dicapai oleh keseluruhan parameter hampir mendekati satu (r1) dan pengaruh nyata. Hal ini menunjukkan adanya keeratan antara waktu pengusangan fisik dengan kadar air, indeks vigor, daya berkecambah serta potensi tumbuh maksimum benih pepaya varietas Callina. Nilai $\mathrm{R}^{2}$ menunjukkan bahwa waktu pengusangan mempengaruhi kadar air sebesar 95.7\%, indeks vigor sebesar 95.9\%, daya berkecambah sebesar 98.2\%, dan potensi tumbuh maksimum sebesar $98.5 \%$.Tanda $(+)$ atau (-) menentukan arah hubungannya, yaitu berkorelasi positif atau negatif.

Korelasi positif $(+)$ menunjukkan hubungan yang berbanding lurus antara kedua peubah. Korelasi negatif (-) menunjukkan hubungan yang berbanding terbalik antara kedua peubah. Korelasi positif $(+)$ terdapat pada tolok ukur kadar air benih. Kadar air benih cenderung mengalami peningkatan seiring dengan peningkatan waktu pengusangan. Korelasi negatif (-) terdapat pada indeks vigor, daya berkecambah serta potensi tumbuh maksimum. Semakin lama waktu pengusangan cepat benih, maka viabilitas dan vigor benih akan semakin menurun. Nilai indeks vigor dan daya berkecambah dijadikan tolak ukur dalam penentuan waktu pelembaban. Perlakuan pelembaban pada 48 jam dan 72 jam berpengaruh sangat nyata pada keempat parameter benih. Perlakuan pelembaban 96 jam berpengaruh nyata pada nilai daya berkecambah. Penentuan waktu pelembaban juga mempertimbangkan pola penurunan viabilitas dan vigor yang paling stabil dan tidak mengalami penurunan secara tajam. Penurunan viabilitas dan vigor benih secara tajam mengindikasikan bahwa viabilitas dan vigor dari lot benih tersebut rendah. Pelembaban 96 jam mampu menurunkan nilai daya berkecambah benih secara gradual dibandingkan perlakuan lain. Pelembaban benih selama 96 jam juga memiliki nilai koefisien determinasi dan koefisien korelasi mendekati satu (r1) pada tolok ukur indeks vigor dan daya berkecambah. Nilai tengah indeks vigor dan daya berkecambah diperlukan dalam penentuan waktu pengusangan efektif yang disajikan dalam Tabel 4. Waktu pengusangan efektif dapat ditentukan dari penurunan viabilitas benih hingga mencapai $50 \%$ akibat pengusangan

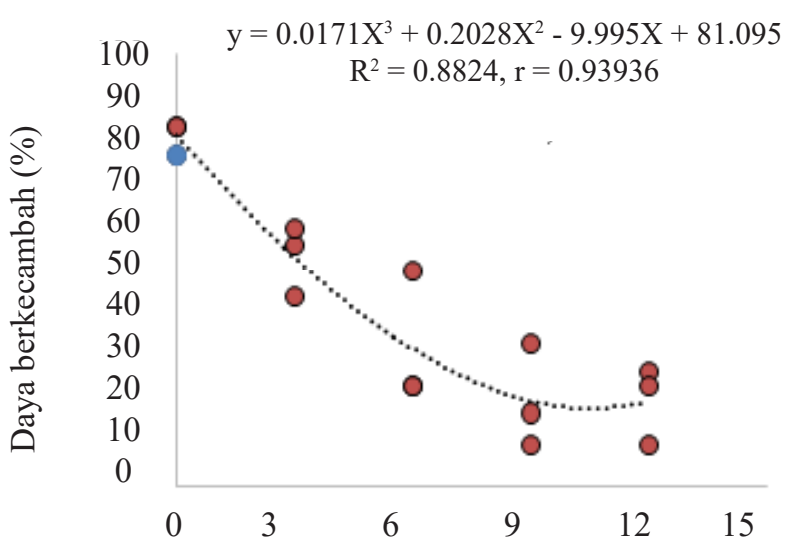

Waktu pengusangan (menit)

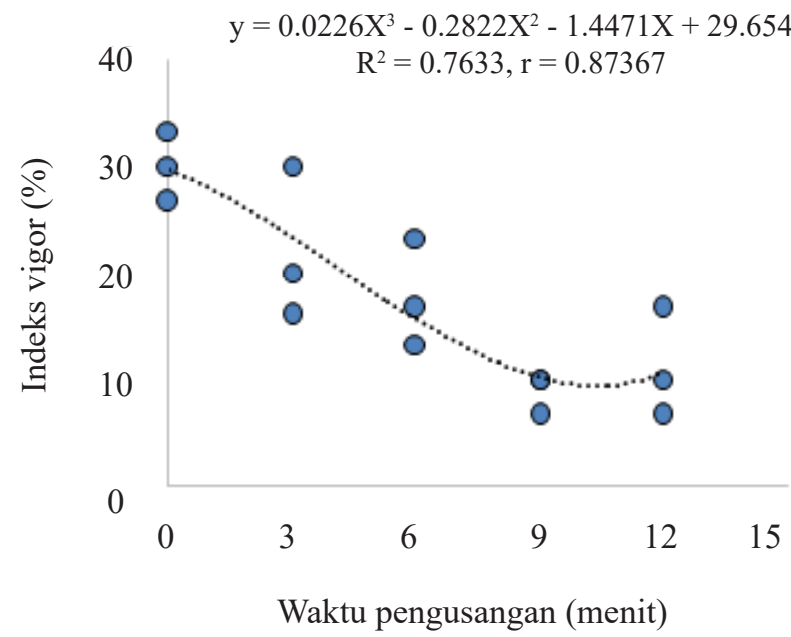

Waktu pengusangan (menit)

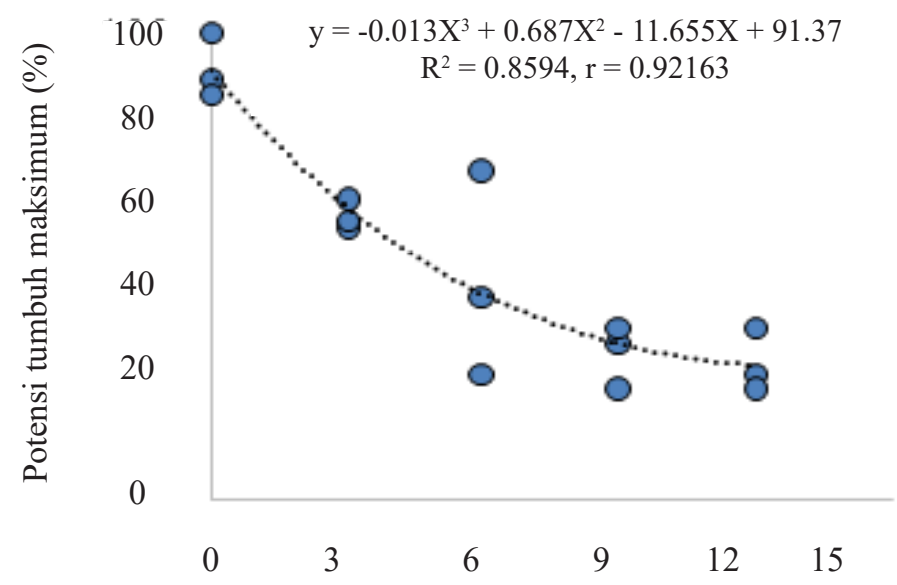

Waktu pengusangan (menit)

Gambar 2. Pengaruh pengusangan cepat fisik terhadap tolok ukur daya berkecambah, indeks vigor, potensi tumbuh maksimum benih pepaya varietas Sukma. 
$\left(\mathrm{P}_{50}\right)$. Pada penelitian ini viabilitas benih di bawah 50\% pada pengusangan $1 \times 3$ menit. Hal ini diduga suhu ruang deraan pada MPC IPB 77-1 MMM sangat tinggi sehingga diperlukan kalibrasi alat tersebut. Penentuan waktu pengusangan dapat dikembangkan dari pola penurunan nilai viabilitas dan vigor yang menghasilkan hasil yang logik. Kriteria waktu pengusangan terpilih adalah yang mampu menjaga devigorasi benih stabil dan tidak ekstrim hingga akhir waktu pengusangan. Pelembaban benih selama 96 jam menghasilkan data penurunan indeks vigor dan daya berkecambah secara lengkap dan logik dibanding waktu pelembaban yang lain. Benih pepaya varietas Callina optimum dilembapkan selama 96 jam pada pengusangan 0x4, 1x4, 2x4, 3x4 dan 4x4 menit. Rekapitulasi hasil analisis regresi dan korelasi benih pepaya Sukma disajikan pada Tabel 5.

Nilai koefisien korelasi (r) yang dicapai oleh keseluruhan tolok ukur hampir mendekati satu (r1). Hal ini menunjukkan adanya keeratan secara nyata antara waktu pengusangan fisik dengan tolok ukur viabilitas, vigor dan kadar air benih. Waktu pelembaban benih selama 48 jam berpengaruh nyata pada tolok ukur kadar air, indeks vigor, daya berkecambah serta potensi tumbuh maksimum. Hal ini sebagai informasi bahwa benih pepaya Sukma cukup baik dilembapkan selama 48 jam tetapi tidak menjadi dasar waktu pelembaban benih karena mengalami penurunan indeks vigor dan daya berkecambah secara ekstrim. Penentuan waktu pelembaban dilihat dari pola penurunan viabilitas dan vigor yang paling stabil dan tidak mengalami penurunan secara tajam. Rekapitulasi nilai tengah indeks vigor dan daya berkecambah benih pepaya varietas Sukma disajikan pada Tabel 6.

Penentuan waktu pengusangan dapat dikembangkan dari pola penurunan nilai viabilitas dan vigor yang menghasilkan hasil yang logik. Kriteria waktu pengusangan terpilih adalah yang mampu menjaga penurunan viabilitas dan vigor benih stabil dan tidak ekstrim hingga akhir waktu pengusangan. Pelembaban benih selama 96 jam menghasilkan data devigorasi secara lengkap dan logik dibanding waktu pelembaban yang lain. Benih pepaya varietas Sukma optimum dilembapkan selama 96 jam pada pengusangan $0 \times 4,1 \times 4,2 \times 4,3 \times 4$ dan $4 \times 4$ menit.

Tabel 3. Rekapitulasi hasil analisis regresi dan korelasi benih pepaya varietas Callina

\begin{tabular}{|c|c|c|c|}
\hline \multirow{2}{*}{ Pelembaban } & Persamaan Regresi & $\mathrm{R}^{2}$ & $\mathrm{r}$ \\
\hline & \multicolumn{3}{|c|}{ Kadar air (\%) } \\
\hline 24 jam & $y=0.003294 x^{3}-0.1488 x^{2}+1.589 x+59.99$ & 0.325 & 0.57 \\
\hline 48 jam & $y=0.01344 x^{3}-0.3455 x^{2}+2.574 x+58.62$ & 0.786 & $0.887 * *$ \\
\hline 72 jam & $y=0.05938 x^{3}-0.2007 x^{2}+2.033 x+57.56$ & 0.957 & $0.978 * *$ \\
\hline 96 jam & $y=0.004427 x^{3}-0.1363 x^{2}+1.315 x+52.93$ & 0.852 & $0.923^{*}$ \\
\hline 120 jam & $y=-0.01469 x^{3}+0.2851 x^{2}-0.8062 x+55.26$ & 0.827 & $-0.909 * *$ \\
\hline \multicolumn{4}{|c|}{ Indeks Vigor $(\%)$} \\
\hline 24 jam & $y=0.000868 x^{3}-0.0402 x^{2}-0.2044 x+13.88$ & 0.749 & 0.865 \\
\hline 48 jam & $y=-0.04785 x^{3}+1.494 x^{2}-14.12 x+38.93$ & 0.95 & $-0.975 * *$ \\
\hline 72 jam & $y=-0.05167 x^{3}+1.609 x^{2}-15.14 x+41.37$ & 0.959 & $-0.979 * *$ \\
\hline 96 jam & $y=-0.00204 x^{3}-0.0151 x^{2}-0.712 x+28.68$ & 0.781 & -0.884 \\
\hline 120 jam & $\mathrm{y}=-0.01157 \mathrm{x}^{3}+0.4211 \mathrm{x}^{2}-5.442 \mathrm{x}+29.82$ & 0.54 & -0.735 \\
\hline \multicolumn{4}{|c|}{ Daya Berkecambah (\%) } \\
\hline 24 jam & $y=-0.07812 x^{3}+2.321 x^{2}-21.48 x+83.29$ & 0.932 & $-0.965 * *$ \\
\hline 48 jam & $y=-0.08601 x^{3}+2.659 x^{2}-25.22 x+77.08$ & 0.982 & $-0.991 * *$ \\
\hline $72 \mathrm{jam}$ & $y=-0.07006 x^{3}+2.291 x^{2}-23.75 x+79.61$ & 0.975 & $-0.987 * *$ \\
\hline 96 jam & $y=-0.05754 x^{3}+1.668 x^{2}-16.76 x+80.93$ & 0.915 & $-0.957^{*}$ \\
\hline 120 jam & $y=-0.07784 x^{3}+1.934 x^{2}-14.47 x+67.32$ & 0.744 & $-0.863^{*}$ \\
\hline \multicolumn{4}{|c|}{ Potensi Tumbuh Maksimum (\%) } \\
\hline 24 jam & $y=-0.05903 x^{3}+1.709 x^{2}-16.07 x+82.28$ & 0.857 & $-0.926^{*}$ \\
\hline 48 jam & $y=-0.08254 x^{3}+2.600 x^{2}-24.99 x+77.04$ & 0.981 & $-0.990 * *$ \\
\hline 72 jam & $y=-0.09208 x^{3}+2.871 x^{2}-27.89 x+87.77$ & 0.985 & $-0.992 * *$ \\
\hline 96 jam & $y=-0.06694 x^{3}+1.836 x^{2}-17.10 x+84.92$ & 0.979 & $-0.989 * *$ \\
\hline $120 \mathrm{jam}$ & $y=-0.03892 x^{3}+1.140 x^{2}-11.26 x+83.10$ & 0.626 & -0.791 \\
\hline
\end{tabular}

Keterangan : $\mathrm{x}=$ waktu pengusangan fisik benih, $\mathrm{y}=$ tolok ukur kadar air, viabilitas dan vigor benih, ** : berpengaruh sangat nyata pada $\alpha=1 \%$, * berpengaruh nyata pada $\alpha=5 \%, \mathrm{R}^{2}=$ nilai koefisien determnasi, dan $\mathrm{r}=$ nilai korelasi. 
Tabel 4. Rekapitulasi nilai tengah indeks vigor dan daya berkecambah benih pepaya varietas Callina

\begin{tabular}{|c|c|c|c|c|c|c|c|}
\hline \multirow{2}{*}{ Pelembaban } & \multicolumn{5}{|c|}{ Waktu Pengusangan (menit) } & \multirow{2}{*}{$\operatorname{Pr}>f$} & \multirow{2}{*}{$\mathrm{KK}(\%)$} \\
\hline & $0 \times 4$ & $1 \times 4$ & $2 \times 4$ & $3 \times 4$ & $4 \times 4$ & & \\
\hline \multicolumn{8}{|c|}{ Indeks Vigor (\%) } \\
\hline 24 jam & $14.0 \mathrm{a}$ & $12.0 \mathrm{a}$ & $10.8 \mathrm{ab}$ & $6.7 \mathrm{bc}$ & $4.0 \mathrm{c}$ & 0.009 & 12.965 \\
\hline 48 jam & $39.4 \mathrm{a}$ & $1.3 b$ & $0.0 \mathrm{~b}$ & $0.0 \mathrm{~b}$ & $0.0 \mathrm{~b}$ & 0.000 & 22.221 \\
\hline 72 jam & $41.9 \mathrm{a}$ & $1.1 \mathrm{~b}$ & $0.0 \mathrm{~b}$ & $0.0 \mathrm{~b}$ & $0.0 \mathrm{~b}$ & 0.000 & 18.363 \\
\hline 96 jam & $28.8 \mathrm{a}$ & $25.0 \mathrm{ab}$ & $21.7 \mathrm{ab}$ & $14.1 \mathrm{bc}$ & $5.2 \mathrm{c}$ & 0.009 & 14.323 \\
\hline 120 jam & $30.0 \mathrm{a}$ & $13.3 \mathrm{ab}$ & $8.4 \mathrm{~b}$ & $4.4 \mathrm{~b}$ & $3.3 b$ & 0.090 & $22.675^{\mathrm{T}}$ \\
\hline \multicolumn{8}{|c|}{ Daya Berkecambah (\%) } \\
\hline 24 jam & $84.0 \mathrm{a}$ & $26.7 b$ & $24.3 b$ & $22.0 \mathrm{~b}$ & $14.7 \mathrm{~b}$ & 0.000 & 8.175 \\
\hline 48 jam & $77.7 \mathrm{a}$ & $10.7 b$ & $5.3 \mathrm{bc}$ & $6.2 \mathrm{bc}$ & $2.7 \mathrm{c}$ & 0.000 & 18.554 \\
\hline 72 jam & $80.5 \mathrm{a}$ & $13.3 b$ & $5.6 \mathrm{bc}$ & $0.0 \mathrm{c}$ & $0.0 \mathrm{c}$ & 0.000 & 9.555 \\
\hline 96 jam & $82.1 \mathrm{a}$ & $32.1 \mathrm{~b}$ & $31.3 \mathrm{~b}$ & $15.8 \mathrm{c}$ & $5.2 \mathrm{c}$ & 0.000 & 21.453 \\
\hline 120 jam & $68.7 \mathrm{a}$ & $30.0 \mathrm{bc}$ & $43.5 b$ & $32.2 \mathrm{bc}$ & $13.3 \mathrm{c}$ & 0.002 & 14.975 \\
\hline
\end{tabular}

Keterangan : $\mathrm{T}$ data ditransformasikan ke $\ln (\mathrm{x}+2)$. Angka-angka yang diikuti oleh huruf yang sama pada baris yang sama tidak berbeda nyata pada uji DMRT taraf $\alpha=5 \%, \mathrm{KK}=$ koefisien keragaman.

Tabel 5. Rekapitulasi hasil analisis regresi dan korelasi benih pepaya varietas Sukma

\begin{tabular}{|c|c|c|c|}
\hline \multirow{2}{*}{ Pelembaban } & Persamaan Regresi & $\mathrm{R}^{2}$ & $\mathrm{r}$ \\
\hline & \multicolumn{3}{|c|}{ Kadar Air (\%) } \\
\hline 24 jam & $y=0.004268 x^{3}-0.1833 x^{2}+2.124 x+62.66$ & 0.805 & 0.897 \\
\hline $48 \mathrm{jam}$ & $y=0.009124 x^{3}-0.2430 x^{2}+1.477 x+64.71$ & 0.574 & $0.758 *$ \\
\hline 72 jam & $y=-0.003294 x^{3}+0.05934 x^{2}+0.1382 x+63.77$ & 0.67 & -0.819 \\
\hline 96 jam & $y=-0.007868 x^{3}+0.1890 x^{2}-0.8657 x+55.61$ & 0.362 & -0.602 \\
\hline $120 \mathrm{jam}$ & $y=-0.001724 x^{3}-0.00429 x^{2}+0.6893 x+57.74$ & 0.598 & -0.773 \\
\hline \multicolumn{4}{|c|}{ Indeks Vigor (\%) } \\
\hline 24 jam & $y=-0.00354 x^{3}+0.2461 x^{2}-6.202 x+51.73$ & 0.878 & -0.937 \\
\hline 48 jam & $y=-0.04694 x^{3}+1.488 x^{2}-14.05 x+37.70$ & 0.958 & $-0.979 * *$ \\
\hline 72 jam & $y=-0.01881 x^{3}+0.630 x^{2}-6.723 x+23.16$ & 0.259 & -0.509 \\
\hline 96 jam & $y=0.00550 x^{3}+0.2431 x^{2}-6.977 x+57.84$ & 0.795 & 0.892 \\
\hline $120 \mathrm{jam}$ & $y=-0.07782 x^{3}+2.501 x^{2}-25.21 x+80.98$ & 0.98 & $-0.990 * *$ \\
\hline \multicolumn{4}{|c|}{ Daya Berkecambah (\%) } \\
\hline $24 \mathrm{jam}$ & $y=-0.05382 x^{3}+1.482 x^{2}-11.19 x+77.43$ & 0.45 & -0.671 \\
\hline 48 jam & $y=-0.107344 x^{3}+2.534 x^{2}-24.99 x+68.61$ & 0.949 & $-0.974 * *$ \\
\hline $72 \mathrm{jam}$ & $y=-0.05012 x^{3}+1.730 x^{2}-19.90 x+79.82$ & 0.953 & $-0.976^{*}$ \\
\hline 96 jam & $y=0.1157 x^{3}-0.1637 x^{2}-2.149 x+75.43$ & 0.874 & 0.935 \\
\hline $120 \mathrm{jam}$ & $y=-0.04723 x^{3}+1.700 x^{2}-20.86 x+90.87$ & 0.984 & $-0.992 * *$ \\
\hline \multicolumn{4}{|c|}{ Potensi Tumbuh Maksimum (\%) } \\
\hline 24 jam & $y=-0.03819 x^{3}+0.9583 x^{2}-6.556 x+77.87$ & 0.258 & -0.508 \\
\hline $48 \mathrm{jam}$ & $y=-0.06129 x^{3}+2.511 x^{2}-27.85 x+91.13$ & 0.976 & $-0.988 * *$ \\
\hline 72 jam & $y=0.00145 x^{3}+0.4067 x^{2}-13.06 x+98.46$ & 0.97 & 0.985 \\
\hline 96 jam & $y=-0.00145 x^{3}-0.0347 x^{2}-0.810 x+85.00$ & 0.851 & -0.922 \\
\hline 120 jam & $y=-0.02448 x^{3}+0.9638 x^{2}-14.77 x+88.98$ & 0.918 & -0.958 \\
\hline
\end{tabular}

Keterangan $: \mathrm{x}=$ waktu pengusangan fisik benih, $\mathrm{y}=$ tolok ukur kadar air, viabilitas dan vigor benih, ** : berpengaruh sangat nyata pada $\alpha=1 \%$, * berpengaruh nyata pada $\alpha=5 \%, \mathrm{R}^{2}=$ nilai koefisien determnasi, dan $\mathrm{r}=$ nilai korelasi. 
Priandini et al. / Comm. Horticulturae Journal 2(3):7-15

Tabel 6. Rekapitulasi nilai tengah tolok ukur indeks vigor dan daya berkecambah benih pepaya varietas Sukma

\begin{tabular}{|c|c|c|c|c|c|c|c|}
\hline \multirow{2}{*}{ Pelembaban } & \multicolumn{5}{|c|}{ Waktu Pengusangan (menit) } & \multirow{2}{*}{$\operatorname{Pr}>f$} & \multirow{2}{*}{$\mathrm{KK}(\%)$} \\
\hline & $0 \times 4$ & $1 \times 4$ & $2 \times 4$ & $3 \times 4$ & $4 \times 4$ & & \\
\hline \multicolumn{8}{|c|}{ Indeks Vigor (\%) } \\
\hline $24 \mathrm{jam}^{\mathrm{A}}$ & $52.7 \mathrm{a}$ & $26.7 b$ & $22.0 \mathrm{~b}$ & $2.7 \mathrm{c}$ & $2.0 \mathrm{c}$ & 0.000 & 16.1226 \\
\hline $48 \mathrm{jam}^{\mathrm{A}}$ & $38.3 \mathrm{a}$ & $2.2 \mathrm{~b}$ & $0.0 \mathrm{~b}$ & $0.0 \mathrm{~b}$ & $0.0 \mathrm{~b}$ & 0.000 & 17.5249 \\
\hline $72 \mathrm{jam}^{\mathrm{B}}$ & $23.3 \mathrm{a}$ & $4.4 \mathrm{a}$ & $1.1 \mathrm{a}$ & $0.0 \mathrm{a}$ & $0.0 \mathrm{a}$ & 0.481 & 21.6511 \\
\hline 96 jam & $58.9 \mathrm{a}$ & $30.0 \mathrm{~b}$ & $26.7 \mathrm{~b}$ & $14.4 \mathrm{c}$ & $32.0 \mathrm{~b}$ & 0.000 & 18.759 \\
\hline $120 \mathrm{jam}$ & $82.0 \mathrm{a}$ & $11.1 \mathrm{~b}$ & $5.6 \mathrm{bc}$ & $0.0 \mathrm{c}$ & $0.0 \mathrm{c}$ & 0.000 & 15.664 \\
\hline \multicolumn{8}{|c|}{ Daya Berkecambah (\%) } \\
\hline $24 \mathrm{jam}$ & $76.0 \mathrm{a}$ & $58.7 \mathrm{abc}$ & $46.7 \mathrm{c}$ & $69,3 \mathrm{ab}$ & $56.0 \mathrm{bc}$ & 0.040 & 15.819 \\
\hline $48 \mathrm{jam}$ & $69.7 \mathrm{a}$ & $0.0 \mathrm{c}$ & $0.0 \mathrm{c}$ & $2,2 \mathrm{c}$ & $17.8 \mathrm{~b}$ & 0.000 & 28.157 \\
\hline $72 \mathrm{jam}^{\mathrm{A}}$ & $80.7 \mathrm{a}$ & $21.1 \mathrm{~b}$ & $11.1 \mathrm{bc}$ & $0,0 \mathrm{c}$ & $0.0 \mathrm{c}$ & 0.000 & 14.1288 \\
\hline 96 jam & $75.6 \mathrm{a}$ & $64.4 \mathrm{~b}$ & $54.4 \mathrm{bc}$ & $45,6 \mathrm{c}$ & $46.7 \mathrm{c}$ & 0.001 & 10.126 \\
\hline $120 \mathrm{jam}$ & $91.8 \mathrm{a}$ & $27.8 \mathrm{~b}$ & $14.4 \mathrm{c}$ & $0,0 \mathrm{~d}$ & $0.0 \mathrm{~d}$ & 0.000 & 11.335 \\
\hline
\end{tabular}

Keterangan : A data ditransformasikan $\mathrm{ke} \ln (\mathrm{x}+2)$, B data ditransformasikan $\mathrm{keln}(\mathrm{x}+10)$. Angka-angka yang diikuti oleh huruf yang sama pada baris yang sama tidak berbeda nyata pada uji DMRT taraf $\alpha=5 \%$, KK $=$ koefisien keragaman

\section{KESIMPULAN}

Pengusangan cepat fisik berpengaruh pada penurunan daya berkecambah benih pepaya varietas Callina dan Sukma dengan persamaan $y=-0.1389 x^{3}+3.3333 x^{2}-25.25 x+81.5$ dan $y=0.0171 x^{3}+0.2028 x^{2}-9.9956 x+81.095$. Waktu pelembaban benih selama 96 jam menyajikan data lengkap penurunan indeks vigor dan daya berkecambah dengan kadar air berkisar antara 63-70\%. Pengusangan fisik benih pepaya optimum dilaksanakan pada waktu $0 \times 4,1 \times 4,2 \times 4,3 \times 4$, dan $4 \times 4$ menit.

\section{DAFTAR PUSTAKA}

[BPS] Badan Pusat Statistik. 2015. Data produksi buah pepaya. http://www.bps.go.id/webbeta/fronted [16 Desember 2015].

Badriah, R. 2012. Pemanfaatan alat pengusangan cepat (MPC) tipe IPB 77-1 MM untuk pendugaan vigor daya simpan benih jagung (Zea mays L.). Skripsi. Institut Pertanian Bogor. Bogor.

[Balitbu] Balai Penelitian Tanaman Buah Tropika. 2011. Rejuvinasi pepaya merah delima. http://balitbu.litbang.pertanian.go.id/ind/ index.php/hasilpenelitianmainmenu46/114inovasiteknologi/654-rejuvinasi-pepaya-merah delima. [09 Maret 2015].

Bhattacharya, J., Khuspe, S.S. 2000. In vitro and in vivo germination of papaya (Carica papaya L.) seeds. Scientie Hortikulturae. 91(2001) : 39-49.
Budiman, D.P. 2012. Uji Pengusangan cepat terkontrol (PCT) untuk menduga viabilitas benih cabai merah (Capsicum annuum L.) setelah penyimpanan. Skripsi. Institut Pertanian Bogor. Bogor

Copeland, L.O., M.F. Mc. Donald. 2001. Principles of Seed Science and Technology. Kluwer Academic Publisher, New York, USA

Demir, I., K. Mavi. 2008. Controlled deterioration and accelerated aging tests to estimate the relative storage potential of cucurbit seed lots. HortScience. 43(5):1544-1548.

Justice, O.L., L.N. Bass. 2002. Prinsip dan Praktek Penyimpanan Benih. Roesli R, penerjemah. Terjemahan dari: Principles and Practic of Seed Storage, PT Raja Grafindo Persada, Jakarta.

[Kementan] Kementerian Pertanian. 2015. Data konsumsi buah pepaya. http;//aplikasi2.pertanian.go.id/ knsumsi/tampilsusenas_kom2_th.php_[18 Desember 2015].

Suhartanto, M.R. 2012. Pendugaan Vigor Daya Simpan. Hal. 46-47. E. Widajati, editor. Dasar Ilmu dan Teknologi Benih. IPB Press, Bogor.

Suhartanto, M.R., R.W. Rika. S. Sujiprihati. 2011. Benih pepaya (Carica papaya L.) : bersifat ortodoks ataukah intermediet?. Prosiding seminar nasional PERHORTI. Lembang. 
Tatipata, A., Y. Prapto, P. Azis, M. Woerjono. 2004. Kajian aspek fisiologi dan biokimia deteriorasi benih kedelai dalam penyimpanan. Ilmu Pertanian 11(2):76-87.

Wiati, A. 2016. Indentifikasi cendawan terbawa benih pepaya (Carrica papaya L.). Skripsi. Institut Pertanian Bogor. Bogor.
Wulandari, R. 2009. Pengujian benih pepaya (Carica papaya L.) dengan penyimpanan suhu dingin. Skripsi. Institut Pertanian Bogor. Bogor. 